Embedding user and community participation and civil engagement in museum display and programming

\title{
Embedding civil engagement in museums
}

BLACK, Graham - graham.black@ntu.ac.uk

Reader in Public History and Heritage Management, Nottingham Trent University, UK

\begin{abstract}
Initiatives over the last decade on both sides of the Atlantic and beyond have sought to reposition museums at the heart of their communities as agents for civil engagement. This paper explores the principles involved in making the role possible, using the example of urban history museums. It argues that this will take time, commitment and careful planning, and will impact on every aspect of the museum's activities. It is an essential task however, reflecting the direction museums should be taking in society in the $21^{\text {st }}$ century, but will only be achieved if there is a change of culture across the profession.
\end{abstract}

\section{Key words}

Museums; civil engagement; community; community empowerment; participation; contribution; evaluation; shared authority

\section{Introduction}

... the majority of museums, as social institutions, have largely eschewed... a broader commitment to the world in which they operate. (Janes 2009, 13)

Across the museum sector, staff and volunteers, governing bodies, academics and politicians are exploring how museums can respond to the 'winds of change' (http://douglasworts.org) in wider society and the responsibility of museums to engage their users in the great issues of the day. This paper focuses on one aspect, namely how museums can actively support community empowerment and civil engagement. It does this through exploring how an urban history museum can move from being a 'state space', presenting a single, 'official' account of the past to being a shared space representing multiple perspectives, and exploring the relevance of the past to people's lives today and in the future. This is a highly appropriate area for discussion at a time when a raft of masterplans for major new city history museums, from Bristol (UK) to Boston (USA), and from Stuttgart (Germany) to Taipei (Taiwan), have all placed civil engagement within their core mission.

The 'great issue' involved is the growing concern amongst western governments about the breakdown of community and a wider collapse of public engagement with democracy. Governmental responses have developed from inter-agency policies designed to combat disadvantage to strategies that seek to empower communities and develop social capital. As public institutions, museums have sought to respond to these issues. The idea of museums partnering communities in planning for the future is not new. However, it is only in the last decade that we have seen the active promotion of the museum sector's capacity to empower communities to engage with the great and the local issues of the day. In the USA, a national 'Museums and Community Initiative' promoted from 1998 by the American Association of Museums following a pilot scheme in Philadelphia led in 2002 to the publication of Mastering Civic Engagement which outlined core principles for museums of greater civic engagement, democracy and community building and challenged USA museums to build and strengthen their community bonds. In Western Europe, where by tradition public bodies have received the bulk of their funding from the public purse, there has been an expectation at national and local level that all such bodies, including museums, will actively support relevant political initiatives. In the UK, regional museums are now receiving funds for the first time from central government, through the Renaissance in the Regions scheme, specifically to support community outreach and learning initiatives. 
Embedding user and community participation and civil engagement in museum display and programming

However, in both the USA and Western Europe, the response by museums to the civil engagement agenda has been piecemeal. Conwill and Roosa (2003) suggest this is due to a lack of the necessary:

... organizational capacity to build stronger community partnerships - i.e., adequate time and money, a strong leadership commitment, an organizational culture that embraces change, and staff skilled at listening to community voices and establishing community relationships'. (Conwill and Roosa 2003)

In my view, underpinning these issues is the need for a transformation in museum culture. The purpose of this paper is to inspire such a culture change, support the promotion of best practice and challenge museums to champion civil engagement.

If museums are to truly commit to this road, we must acknowledge the problems involved. A history museum seeking to achieve a participative relationship with its local communities should be committed to incorporating their voices and life experiences. It should work to connect present and past, enabling people to make fundamental links with the past lives of their own communities and thereby draw out commonalities. It should encourage and support audiences to become actively engaged with displays and programming, and to contribute directly to content. Through enabling communities to discover their area's past, and its relevance to the present, the museum should also reveal to local people and communities the importance of having an active role in decision-making for the future. So there is the challenge - can these ambitions be delivered in practice? If they can, it will not be a passive undertaking. Rather, the museum must focus on actively encouraging participation.

\section{Defining civil engagement}

I have specifically used the term 'civil' rather than 'civic'. In the UK, civic tends to relate to public institutions. My belief is that museums should seek to encourage and support engagement within wider civil society, not just with public bodies. I adhere to the working definition of civil society put forward by the London School of Economics Centre for Civil Society:

Civil society refers to the arena of uncoerced collective action around shared interests, purposes and values. In theory, its institutional forms are distinct from those of the state, family and market, though in practice, the boundaries between state, civil society, family and market are often complex, blurred and negotiated. Civil society commonly embraces a diversity of spaces, actors and institutional forms, varying in their degree of formality, autonomy and power. Civil societies are often populated by organisations such as registered charities, development non-governmental organisations, community groups, women's organisations, faith-based organisations, professional associations, trades unions, self-help groups, social movements, business associations, coalitions and advocacy groups. (Centre for Civil Society, 2004)

I believe that it is only through more people playing an active role in civil society that we can hope to strengthen our democracy, by empowering individuals and communities to believe they can help to shape their own futures.

\section{The urban history museum and civil engagement}

Cities are the defining artifacts of civilisation. All the achievements and failings of humanity are here... We shape the city and then it shapes us. (Reader 2004, 1)

Over half the population of the world now lives in an urban environment. While it is in developing countries that the greatest urban growth is occurring, Western towns and cities are also witnessing rapid change physically, in the nature and diversity of their population, and in the employment opportunities they offer. It is to neighbourhoods within these towns and cities that Western governments most frequently point when speaking of societal 
Embedding user and community participation and civil engagement in museum display and programming

breakdown. If museums are to have a meaningful role in civil society in the $21^{\text {st }}$ century, that role will be forged in this urban environment. For urban history museums, that means emerging from the safe environment of an 'official' past to explore critically the different perspectives of the communities in their localities. It means encouraging debate about the impact of the past on the present. It means taking an active role in the present - and the present is a different challenge in that it is happening now and changing all the time; it is out there in the streets of the city, not inside the museum walls.' (Jones, 2008, 8). It means using the past and present to support the development of their localities as learning communities so that people can have an informed involvement in decision-making about their futures.

The best museums inspire, excite, empower, give confidence and help individuals and communities grow. Pilot research at Bristol and Tyne \& Wear museums outlines the positive impact museums can have on individuals (AEA, 2005). Strong institutions like museums and libraries are recognised by many in the communities they serve as essential to community well-being, while the "sense of place" that is conveyed through history museums and historic preservation is a key element in helping a community understand its uniqueness (Wilkening and Chung 2009, 4). Given the difference they can make to people's lives, museums have a duty to the communities they serve, and who fund them, to play a civil engagement role. In business terms, this will also prevent the marginalisation of museums within their localities, help museums to build sustainable audiences and prove relevance to funding bodies.

This paper argues that five core principles provide the essential underpinning that would enable urban history museums (and others) to actively support civil engagement:

1. Urban history museums as memory institutions can collect, conserve, document and represent the cultures and life experiences of all those who live within their localities, helping to create an inclusive civil environment.

2. Urban history museums as learning institutions can help to develop informed individuals and communities who can contribute positively to decision-making about their future lives.

3. Urban history museums as social institutions can reach out to, welcome, support and represent the many voices within the communities they serve in partnerships of equals.

4. Urban history museums as democratic institutions can actively promote civil dialogue and reflective participation in civil society.

5. Urban history museums as responsive institutions can work to change their organisation and culture to meet the needs of contemporary society.

The first three of these principles are well established across the museum sector. Few museums would be starting from scratch on the journey to support civil engagement. Instead, we can begin by identifying the civil dimensions of our existing work, use that to persuade colleagues and then reach outwards with commitment (Thelen, 2001).

\section{Museums as memory institutions}

A museum is the memory of mankind ...

Philippe de Montebello, formerly Director of the Metropolitan Museum of Art, New York, quoted in USA National Public Radio broadcast, A History of Museums, 24 November 2008

There is a long-established association of memory with preservation and storage. It is in this sense that the museum is much more than a typological collection of evidence of past time frames but is, rather, the storehouse and protector of the memory of humankind, through the 
Embedding user and community participation and civil engagement in museum display and programming

objects, including oral histories and sites, held in its collections. Such objects represent the visible, audible and touchable outer world of the memory of past societies - a cultural memory that can last thousands of years but is also relevant to recent times.

In collecting these objects, museums not only store cultural memory, they are also directly involved in creating and manipulating it:

Preservation in the museum fixes the memory of entire cultures through representative objects by selecting "what 'deserves' to be kept, remembered, treasured..." (Crane 2000, 3)

In the context of civil engagement, it is particularly important to recognise the partial nature and idiosyncrasy of what was deemed worthy of keeping in the past. One can link the gaps in collections to major historical silences, and to past collecting policies relating to the priorities and tastes of the ruling elite within a community - reinforcing the view that museums represent a selective, elitist view of the past. Yet in recent decades museum engagement with wider communities, and desire to represent multiple perspectives, has been reflected in the re-visiting of existing collections to draw out new relevances and in proactive approaches to contemporary collecting that ensures the representation of previously disenfranchised communities. Civil engagement is underpinned by a sense of inclusion and representation. Museums, through their collection and representation of once excluded communities can play a key role in this:

In this process of transformation from the position of traditional cultural authority to a new role as cultural mediators in a more multicultural environment, museums redefine their strategies of representation of the past and find space for marginalized memories. (Misztal 2003, 20)

\section{Museums as learning institutions}

We're talking about building learning communities... [it is] essential for a healthy democracy and civic well being to have educated citizens.

Marsha Semmel, Institute for Museum and Library Services, USA, quoted in Falk, Dierking and Foutz 2007, xvi

There has been a growing acceptance within the museum profession that museums are primarily institutions for public learning. Substantive research has shown that museums are natural locations for what Falk and others have called free-choice learning (Falk and Dierking, 2002). The opportunities for museum learning tend to be unpressured and openended. Museum display and programming can involve all the senses and create diverse stimuli and responses. This works with a wide variety of audiences, and can reflect a range of opinions, interests, needs and expectations. It involves active engagement of the mind and can be extremely enjoyable.

Developing museums as centres for free-choice learning means comprehensively changing our relationship with visitors to one of partners on a learning journey where the museum acts as a supporter and facilitator, poses questions and reflects multiple perspectives from which visitors can construct their own meanings. In this more flexible learning environment, visitors must also play a more active role, taking more control of their own learning, creating personalised learning experiences and potentially contributing to content in a three-way conversation with the museum and other visitors.

All of this provides a framework within which the museum can potentially thrive as a social and democratic institution. The revival of the learning role has transformed the organisation and mission of many museums and has also brought home to museums the importance of partnerships with other agencies and with the communities they serve. The role that museums as learning institutions can play in building stronger communities will be much more effective if carried out in partnership with others. 
Embedding user and community participation and civil engagement in museum display and programming

\section{Museums as social institutions}

My focus here is on user contributions and the representation of multiple perspectives. Creating a friendly, welcoming external image and museum environment remains central to any ambition to engage communities with museums but has been written about extensively elsewhere (e.g. Black 2005, 2008; Falk and Dierking 2000; Gurian 2006; Hood 1993) and was recently commented on by Falk:

The number one criteria [sic] of all my subjects - black and white, frequent visitor, occasional visitor, or non-visitor - was feeling comfortable and at ease in one's surroundings... and nearly all also valued social interactions. (Falk 2009, 49)

An urban history museum committed to civil engagement will actively encourage user contributions to content and seek to represent multiple perspectives. History museums have frequently been criticised as institutions that help to create and underpin an authorised collective memory. Their process of selection, documentation and presentation was seen as legitimating a particular construct - rather than representing a multiple past, museums were believed by their critics to present an 'official' version. They did this partly through the kinds of narratives and ways of thinking they presented but perhaps most powerfully through their silences - 'in what it allows to go unnoticed, unrecognized and unacknowledged' (Mezaros 2008 , 243). The 'new museology', opened the gates to pluralism and multiple perspectives, while the rise of oral history as a discipline had a profound effect, as museums incorporated the lived experiences of ordinary people into display content. Today, many history museums have replaced the single authoritative voice with a representation of many voices and multiple perspectives. They have done so by:

\section{Ensuring content is inclusive}

- Researching and integrating diverse aspects of history and heritage into displays and ensuring representative interpretation

- Involving diverse cultural and community groups in developing displays, resources and interpretation

- Working with groups and communities to research and celebrate memory

- Developing imaginative events and activities to highlight the diverse nature of heritage.

(after Wong 2002, 7)

\section{Using a wide spectrum of sources}

Incorporating objects, pictures and moving electronic images, written texts, oral narratives, smells, sounds, voices and music is a key starting point. This both ensures a multi-sensory approach and provokes a lively and critical historical dialogue about the past.

\section{Developing user-generated content}

A museum committed to community participation will actively seek user contributions in its galleries, in programming within the locality and online, making the museum a public space for opinion- and meaning-making, for public discourse and inclusion. Content could include:

- Community participation in exhibition development

- Community exhibits incorporated into long-term displays and the museum website.

- Incorporating contemporary responses to the collections

- The voices of users incorporated into displays, for example through comment cards, recorded content and online

- Opportunities to meet with staff and communities

- Seating as a tool to encourage social interaction

- Opportunities to join interactive discussions on the website. 
Embedding user and community participation and civil engagement in museum display and programming

\section{Mounting temporary exhibitions}

Partnering community groups will encourage ownership of exhibitions and events, ensure changing content in the museum and add to the provision of multiple perspectives. Some subject matter works better in temporary displays, while on other occasions, it can provide an opportunity to experiment before incorporation into permanent content. Temporary exhibitions can also act as a focus for community-led research, while their public display engenders pride and confidence in participants.

\section{Becoming a museum without walls}

Urban history museums must go outside their walls and also not be restricted to set opening hours. The museum's most important exhibit is the locality it serves and the museum should both encourage local communities to share their experiences with visitors and encourage users to go out and actively explore the locality, using local voices (live or audio) to reach below the surface patina to develop a real understanding.

New technology is transforming the capacity of the museum to reach outwards and is critical to the museum's $24 / 7$ role and in promoting civil engagement, particularly as it changes from being primarily a source of information to an opportunity for networking. As well as the more traditional roles for the website, many museums are already recognising the potential to go much further (Samis, 2007).

\section{Building stories on what life is like in the locality now}

Oral and written testimonies, short films, soundscapes and images contribute to a wider understanding of a locality's complex culture and history, and could include the recording of personal experiences/life stories as part of the museum's role as a repository of community memory. These could also link to contemporary collecting which would engage with diverse audiences to capture a multitude of connecting narratives, while partnerships, for example with regional and community media, would enable the museum to incorporate up-to-theminute stories. As previously suggested, town trails, developed by individuals and communities, would take people outside the museum walls - exploring the area through many eyes.

\section{Peopling and programming in the galleries}

A key way of including many voices and multiple perspectives in the museum is through people in the galleries - staff and volunteers - and the associated programme of activities, from storytelling, object handling and gallery tours to the organisation of debates. It is essential that spaces are designed in for these. Staff roles must be carefully defined before appointment and a wide range of community volunteers sought to ensure different voices are heard. Actively seeking community involvement and offering training, and perhaps payment where this helps people recognise that their commitment is valued, will be an ongoing task.

In addition to the need to develop new collections, discussed above, other problems associated with developing a multi-perspectival approach have yet to be resolved. These include:

\section{Sharing authority}

Raising the issue of shared authority means confronting a primary fear of all professionals, not just museum curators, of their expertise not being recognized and of losing control. But, if a museum is committed to reflecting the voices of the communities it serves, curators must be willing to share authority for content. This is best achieved in a partnership of equals. In Leicester, for example, the museum service worked with groups from the local Asian community to create an exhibition and website on their experiences of moving to England. This was part of a national project (www. movinghere.org.uk), which involved over 35 archives, museums and libraries and 45 community groups. For Leicester Museums, 
Embedding user and community participation and civil engagement in museum display and programming

projects like this are vital. The city will be the first in the UK where no ethnic group forms a majority of the population.

In projects like 'Moving Here', individual and community users of the museum bring their ideas, feelings and personal connections with them, while the museum acts as a 'mediator of many voices' and provides the context that enables people to reassess these within a 'bigger picture' of the past:

Memories stand on their own; a good history exhibit provides context. We had to somehow join the two. Just as important, from my point of view, we needed to allow thoughtful visitors to reflect on the very nature of memory and history. To allow visitors to understand the value of both approaches to the past would be an important contribution... The way to do this was to share the job of interpretation, of creating meaning with our visitors. (Lubar 1997, 18)

A true sharing of authority with users and communities should individuals and communities direct involvement in the selection of which issues to address and in the production of historical knowledge. This raises a further issue in that a shared authority must always be underpinned by the understanding that with such authority comes trust - the trust of museum users in the content provided. In this situation, we can also see a potential direct conflict between history and community memory, with popular historical knowledge tending to reflect a highly selective interest in the remains of the past that is shot through with present-day assumptions (Tosh 2006, 12-13). The issue of the museum retaining editorial control must be addressed early in any potential partnership.

\section{Incorporating selective perspectives}

There is a risk that museums incorporate selected perspectives into their content, effectively inviting in some previously marginalised groups to become part of the 'authorised version' of the past. Museums must be vigilant in avoiding a tendency to keep working only with those community groups that they have become comfortable with. There is an equal risk of giving too much space to those groups which have the strongest sense of community identity and have pushed hardest to have their stories told. Unless museums devise processes to counteract such tendencies, the less organised will remain silent and marginalised.

\section{Competing versions of the past}

... groups of people sharing many of the same experiences and much the same framework for interpreting them - will perfectly rationally be different from one another in the way they see the world. (Goodin 2003, 42)

Seeking to reflect multiple perspectives will not necessarily lead to harmony. There are competing versions of history within and between communities and generations and differing versions of the past constantly compete for control of the present. For many previously marginalised groups, shared 'memories of past injustices are a critical source of empowerment' (Misztal 2003, 18). Not all previously marginalised communities will welcome opportunities for inclusion in existing museums. In fact, there has been a profusion of communities creating their own museums. For me this is a huge concern. It brings in issues around, for example, who owns the past or the differing bias in presentation that these museums present. And how are we, in these circumstances, to encourage people to reflect on the experiences of others?

Conflicting perspectives on the past represent both a problem and a challenge. There is a need to develop approaches to display that engage people with the points of view of others and encourage reflection and understanding, the basis of the next core principle.

\section{Museums as democratic institutions}

Democratic citizens are supposed to act reflectively... Democratic citizens are supposed to come to some joint determination of what they collectively ought to do... Democratic citizens 
Embedding user and community participation and civil engagement in museum display and programming

are supposed to act responsively, taking due account of the evidence and experience embodied in the beliefs of others. Democratic citizens are supposed to act responsibly, taking due account of the impact of their actions and choices on all those (here or elsewhere, now or later) who will be affected by them. (Goodin 2003,1 )

Goodin sees this discussion of a reflective democracy as representative of ideal standards unlikely to be achieved in the real world. But it does lead one to question what role museums can realistically play in supporting engagement and participation in civil society. What is there that museums do well that will support reflective participation in society?

\section{Museums as social institutions}

Museums have the potential to attract people who are radically different to each other. Institutions that facilitate social, cultural and generational mixing are a core underpinning for a civil society. If we wish to support civil engagement we need to build on these qualities, reaching out to wider audiences and, through our approach to display and programming, encouraging conversation between visitors.

\section{Museums as inclusive institutions}

Issues of inclusion and exclusion are central to democracy - who feels a part of civil society, who does not, and why? Who feels their voice is heard and who does not? Representing diverse communities and the multiple perspectives they bring has been discussed above. But representing diversity is not enough. Museums must also ensure those representations are widely communicated. Equally, representing the previously silent, marginalised, spoken for and excluded involves not only minority communities but also, for example, children, those not yet born and the non-human inhabitants of the planet.

\section{Museums as potentially neutral places can open dialogue on the contentious}

This sits at the heart of the museum's ability to play an active role in contemporary society. The museum is an ideal location to act as a catalyst for unleashing comment, conversation, ideas and emotion from both local people and users from further afield, particularly about issues of contemporary relevance to a locality. Cameron (2005) explores public attitudes to the presentation of contentious issues in museums in Australia, noting that 'bringing important, challenging and controversial points of view in a democratic, free-thinking society was seen as a key role for museums by many.' But questions remain over the extent to which museums can challenge and criticize as opposed to explore viewpoints. Cameron's research on 'Exhibitions as Contested Sites' (Cameron 2003, 2005) is important here:

Should they act as provocateurs, leaders of public opinion and offer transformative spaces to challenge and change views? Or are museums to be safe civic places for the exploration of a range of views? Can museums take on a social activism role, to assist in the resolution of issues on a personal or political level or should they be places for non-challenging social experiences? Alternatively can museums be all of these things at once? (Cameron 2003, 4)

Responses to contentious issues are unpredictable, and arouse strong opinions and emotions. The museum must, therefore, be very clear on how it presents the contentious and in defining its objectives.

\section{Museums as reflective institutions}

...much of the work of understanding others... is done inside your own head, imaginatively projecting yourself into their place. (Goodwin 2003: 228)

Communicating inclusive content and multiple perspectives, and presenting contentious issues, will only be effective as a tool for civil engagement if it leads to reflection and thus to greater understanding and more informed decision-making. Museums must build in opportunities for users to reflect and review the experiences of their visit, augment their understanding and voice their own theories and opinions: 
Embedding user and community participation and civil engagement in museum display and programming

- Displays could lead with statements and artefacts from a range of viewpoints

- If relevant, these could be supported with scrapbooks of newspaper articles, flipbooks, etc., presenting different perspectives, so that users can develop informed opinions

- Discussion could be encouraged by users posting or recording their comments for others to share. Cooks wrote of this in relation to a travelling exhibition (What about Aids) that she helped to organise:

Our experience dealing with strong feelings around this exhibit made us realise that we needed a place where visitors could safely express their views... We also covered a wall with visitors' positive and negative comments to let people know this was an exhibit that welcomed many different points of view. (Cooks 1999, 19)

- Well-designed seating areas can be central to encouraging discussion and reflection.

The use of interactive technology to encourage reflection and discussion, and to elicit responses from visitors, is only just being recognised. See, for example, the 'Room of Opinion' in the Re-tracing the Past exhibition at the Hunt Museum, Limerick (Ciolfi, Bannon and Fernström 2008). Better known is the Free2Choose exhibit at the Anne Frank House in Amsterdam, which invites visitors to reflect and then vote on a variety of human rights issues in a way that allows users to compare their own votes with those of others participating at the same time and with 'all visitors' (Simon 2008b). In a wider context, outreach projects and the museum website play an important role in taking 'Museum Conversations' beyond the museum.

Museums as centres for dialogue and debate

Dialogue between a museum and its visitors, and between visitors, can take many forms. The use of visitor contributions within museum exhibitions has been discussed above. But, while exhibitions have a core role to play, museums committed to promoting civil engagement must place much greater emphasis on the role of programming.

McRainey (2008) discusses how the whole approach to programming at the Chicago History Museum was re-planned in the lead-up to the major refurbishment which was completed in 2006 , moving 'the interpretive focus in program design away from an exhibition-centred approach to one that is creating new connections between adults, history and the city'. The programming includes 'panel presentations, forums for debate, seminar discussions and tours' that together 'offer participants multiple points for exploration and diverse perspectives for meaning-making'. It is the forums that most obviously reflect the new role the museum has taken in supporting civil engagement. These were carefully planned, following audience studies, to include 'diverse perspectives for new insights into topics; primary voices of individuals who have first-hand knowledge; and dialogue among panellists as well as between panellists and participants'. There is no opportunity for the museum to rest on its laurels:

With the recurring monthly schedule, the structure challenges staff to demonstrate their nimbleness and flexibility in program design in timely responses to stories that headline local papers and issues discussed in community centres. (McRainey 2008, 40)

So, museums can be effective centres of debate, including dialogue between past, present and future, but this type of initiative is not one to undertake without appropriate resourcing. Equally, while it might work with adults who already possess a high level of understanding and experience of debate, a different approach would be required to engage young people or socially disadvantaged communities. Jolly points to the use of 'Talking Circles' at an exhibit entitled 'RACE' at the Science Museum of Minnesota in 2007: 
Embedding user and community participation and civil engagement in museum display and programming

Talking Circles... are facilitated discussions for groups of 20 or less... in which all participants are invited to reflect on their experiences in learning about and experiencing race as a factor in their lives and communities. [More than 4000 people in visiting groups participated, a] 'valuable, non-confrontational way to explore difficult issues in a safe environment' (Jolly $2008,90)$.

The Centre for Cultural Understanding and Change at the Field Museum in Chicago established a programme that reflects common concerns across the region defined through over one hundred conversations held with communities and organisations in 2007 . The Centre defines its mission on its website:

The Centre for Cultural Understanding and Change (CCUC)... uses problem-solving anthropological research to identify and catalyse strengths and assets of communities in Chicago and beyond. In doing so, CCUC helps communities identify new solutions to critical challenges such as education, housing, health care, environmental conservation and leadership development. Through research, programs and access to collections, CCUC reveals the power of cultural difference to transform social life and promote social change. (www.fieldmuseum.org/ccucl)

The website, in outlining current projects and programmes, illustrates how effectively this works in practice.

In 2004, the Levine Museum of the New South accompanied its Civil Rights exhibition COURAGE: the Carolina Story that Changed America with a civil dialogue component, "Conversations on COURAGE" (Deuel et al, 2007). There was a real concern that the current civic and corporate leadership in Charlotte knew little of the historical background so the specific aim here was 'to use history to help engage current leaders in contemporary issues of race, education and social justice.' The ambition was to bring in corporate leaders and their lieutenants to visit the exhibition in teams and then spend an hour in a facilitator-led discussion, making the shared experience into a long-term reference point. The "Conversations" proved highly successful, with 111 teams taking part, from the police chief and his staff to the Bank of America. This proved to be the first of a series of successful projects, with civil dialogue now a standard part of the museum operation, and a new phrase to sum up the museum mission: "Using History to Build Community".

However, clearly not all visitors want to actively debate issues. If museums are to become effective centres for civil engagement, it is essential that we have a greater understanding of the differing levels of participation that we offer, the willingness or otherwise of our users to engage, and the ways in which the environment we create supports or discourages that participation. Simon (2007b) explores differing levels of participation and the barriers between them:

Level 1: user passively receives... A successful level 1 experience features content that is meaningful and interesting to viewers.

Level 2: opportunity for user to play with content. The content may be responsive to you, but the interactive experience is non-networked.

Level3: individual interaction with content is networked so each individual's interaction is available, in a limited capacity, to the entire group of users (e.g. voting)...

Level 4: individuals still do their interaction with the content singly, but their interactions are available for comment and connection by others. A successful level 4 experience uses social interaction to enhance the individual experience...

Level 5: ... the holy grail of social discourse, where people interact directly with each other around content. Healthy level 5 experiences promote respect among users, encourage community development, and support interaction beyond the scope of the content.

(after Simon 2007b) 
Embedding user and community participation and civil engagement in museum display and programming

Simon believes that if we want to engender debate, we must encourage direct interaction. But, as responses to Simon's blog make clear many, perhaps most, visitors prefer the anonymity we currently offer. There must be a major question mark over whether direct interaction can be a part of a 'normal' gallery visit rather than in a planned forum or debate.

\section{Museums as active promoters of civil participation}

In the Power of Children exhibition at the Indianapolis Children's Museum, children meet the stories of Anne Frank, Ruby Bridges and Ryan White which are used to show that every individual can make a difference. The exhibition culminates at the 'Tree of Promise', where:

... children make a promise [that will impact or change the world], which floats up into the tree as a digital leaf. Those promises are then emailed home... and families can then elect to join the Tree of Promise social network... If at-home users complete their promises they can return to the museum, where the tree "remembers" and congratulates them... In this way, the "Tree of Promise" takes a quick participatory in-museum experience - writing down a promise - and provides a supportive platform on which users can cultivate and substantiate that action. (Simon 2007a)

Should museums behave in such a specifically social activist way, or is their primary role to encourage reflection?

\section{Museums as institutions that evaluate their own actions}

If museums seek to promote civil engagement, they must define outcomes and establish effective ways of evaluating performance. Such evaluation depends vitally on museums acknowledging failure as well as success. It must explore the issues that evaluation raises for the whole institution, not just for individual exhibitions or projects. It must focus on the effectiveness of visitor engagement, the contributions they make and the meanings they construct. Sharing experience and expertise is core to moving us all forward.

A range of articles provide a starting point for the debate on evaluation that we need to have. Worts has spent more than a decade exploring the opportunities open to museums that seek to serve the cultural needs of individuals and communities, and how museums measure their successes and failures in this field. His article 'Measuring Museum Meaning: A Critical Assessment Framework' (Worts 2006) discusses the development of evaluative approaches and performance indicators, such as the extent to which the museum addresses vital community needs and acts as a catalyst for action. The Inspiring Learning for All initiative in the UK (www.inspiringlearningforall.gov.uk) uses 'Generic Learning Outcomes' (GLOs) and 'Generic Social Outcomes' (GSOs) to evaluate the impact of museum programmes on individuals. Economou (2004) outlines the range of evaluation approaches she developed at Kelvingrove Museum and Art Gallery, Glasgow, creating a strategy which she suggests 'addressed evaluation holistically, and planned extensively and in-depth how it could be used as a useful tool to support the key activities throughout the organisation' (Economou $2004,31)$. Mclean and Cooke $(2003,161)$ in their interviews of visitors to the then newly opened Museum of Scotland were able to show that 'Rather than reading a one-dimensional static narrative of a nation, the visitors constructed multifarious readings that reflected both their individual identities and their collective identities in an imagined community'

\section{Museums as responsive institutions}

the responsibility of civil society organizations [is] to purposefully craft missions that enable participation in public life...' (Janes 2009, 21).

If there is to be more than a piecemeal response to the civil engagement agenda, it will only come about if museum organisations and their staff are committed to it. For this to happen, wider museum culture will have to be transformed. 
Embedding user and community participation and civil engagement in museum display and programming

Museum staffing and organisational structure is rarely designed to reflect community. Achieving change to drive a civil engagement agenda will require focus on both organisational and individual change. The pressure of the day-to-day combined with the established culture of an organisation pre-disposes it to remain the same while, unless the organisation is supportive, individual staff development is unlikely to happen. There are few published accounts of the change process in museums. Abraham, Griffin and Crawford (1999) provide a strategic overview of the processes used to manage change in twenty-four museums in Australia, Canada, the UK and USA, concluding in a later paper that:

The effective management of change in museums is characterised by patient and considered leadership... able to translate external needs to internal vision and then to employee action, integrate tasks, structures, processes and systems at the technical, political and cultural levels and integrate management practices to build internal and external unity. (Griffin and Abraham 2001, 336)

When David Fleming, director of National Museums Liverpool refocused his organisation he:

- Produced a new vision to provide clarity of purpose, with a focus on audiences and the social role of museums

- Created a new senior management to provide coherent leadership;

- Embedded planning at all levels, from corporate to individual forward job plans

- Created a new staff structure to promote teamwork and cross-departmental working

- Developed a new style of involvement of staff in decision-making

- Generated greater political and media awareness

- Elevated the value of staff training and development

- Promoted or recruited 'change agents' within the staff to act as missionaries

- Raised ambitions

- Discouraged factionalism and disrespect for the work of others

- Encouraged risk-taking and innovation

- And underpinned all of this with careful financial management.

(Fleming 2005)

Fleming, as director of a national museum in the UK, is answerable to an independent Board of Trustees and it is notable that his paper makes no mention of the Board's involvement in such profound change. I cannot imagine this scale of change being achievable in the USA without active Board participation, but most urban history museums in the UK face a different problem. They are funded by, and under the control of, elected local authorities. Most museum managers sit low down within departmental hierarchies and must react to agendas imposed from above rather than having direct access to their governing committees and being able to define agendas. Change in these circumstances is much more difficult - you are fighting against not only the organisational culture of the museum, but also against that of the local authority.

The transformation of wider museum culture is an even greater challenge. A parallel here is with the campaign to re-establish learning as a core function of museums. For example, in the UK this became part of the national political agenda following the election of New Labour in 1997 with Prime Minister Tony Blair's commitment to 'Education, Education, Education'. The publication of David Anderson's A Common Wealth in 1997 was followed by the Inspiring Learning for All (ILFA) initiative led and funded by the national strategic body, the Museums, Libraries and Archives Council. This campaign brought staff and funding for learning and outreach projects nationwide, a website as a driving mechanism (www.inspiringlearningforall.gov.uk) and the development of an evaluative process. ILFA is ongoing and there is still substantial central government funding underpinning it. Yet the key word here is 're-establish'. Museums have always been recognised as learning institutions but during the $20^{\text {th }}$ century this function had been downgraded. Learning is now being restored to its rightful place, but this process still has some way to go. 
Embedding user and community participation and civil engagement in museum display and programming

By comparison, the AAM's Museums and Community Initiative has begun the process of establishing core principles related to community empowerment (see above) and also of developing toolkits to support museums and museum personnel along the route but, in Western Europe, there is as yet little comparable development. Funding and activity continue to focus on the narrower field of audience development. Yet there is a parallel in UK universities:

'Engagement' is an important word in modern society. We believe that a closer relationship with Higher Education helps empower people to take an informed part in the democratic process and the decisions affecting their lives'

Alan Thorpe, Chief Executive of the UK Natural Environment Research Council

UK universities and their various Higher Education research councils came together in 2008 to establish a pilot Beacons for Public Engagement initiative, including a National Coordinating Centre for Public Engagement (NCCPE), with an initial budget of $£ 9.2 \mathrm{~m}$ over four years, whose roles are to inspire culture change in how universities engage with the public and to promote best practice (www.publicengagement.ac.uk). As learning institutions and public bodies, British universities are recognising the role they could and should play in civil society. The scale of this pilot project acknowledges the long road ahead in changing the internal culture of universities. How much longer and more difficult is the road for the museum sector?

\section{Conclusion}

Urban history museums can no longer afford to hide behind their walls in the safe confines of the 'official' past. As social institutions and public bodies they have a duty to contribute to the well-being of contemporary society and to work to improve people's lives. Part of this duty involves empowering local people and supporting their engagement with civil society. Many museums are already engaged in this, and frequently to a greater extent than they realise, as an evaluation of existing activity based on the principles outlined above will reveal. From the basis of work already being done, museums can re-evaluate their underpinning culture and re-focus their organisations so that they can reach out to wider society with a clear vision of their role and the capacity to achieve it.

No one would claim that this is an easy task, that it can be achieved rapidly, or that museums can succeed on their own. This paper has, however, sought to lay down core principles for the road ahead and to support individual museums and staff who wish to begin the journey. We are in urgent need of more museums to act as 'beacons for public engagement'.

\section{Acknowledgement}

With thanks to Julie Finch, Director of Bristol Museums, and Kevin Osbon of Focus Consultants for starting me on this journey. Real and email conversations with Katja Mieth, Director of Museum Affairs of the Free State of Saxony, Germany and Mette Boritz, of the National Museum of Denmark, Copenhagen added extra dimensions to the article. Carolyn Batstone of the Open University read and raised important issues on the final draft. I owe a particular debt of gratitude to the three anonymous reviewers whose comments made a considerable difference to the final article.

\section{Biography}

Graham worked as an archaeologist before moving into museums, becoming Senior Curator of Nottingham Castle Museum in 1983. In 1988 he left to become a consultant in heritage interpretation. Since 1995 he has combined this with his academic role on the postgraduate Museum and Heritage Management course at Nottingham Trent University. Exhibitions on 
Embedding user and community participation and civil engagement in museum display and programming

which he has acted as interpretive consultant have won many awards, including the first UK $£ 100,000$ Museum Prize (2003). His publications include The Engaging Museum (Routledge, 2005) now in its fifth reprint.

\section{Bibliography}

AAM. 2002. Mastering Civic Engagement, Washington: American Association of Museums.

Abraham, Maurice, Des Griffin and John Crawford. 1999. Organisation change and management decision in museums. Management Decision 37(10): 736-751.

AEA Consulting. 2005. Tyne \& Wear Museums, Bristol Museums, Galleries and Archives: Social Impact Programme Assessment, London: AEA Consulting. Available at www.twmuseums.org.uk/about/corporatedocuments/documents/Social Impact.pdf (Accessed March 2008).

Anderson, David. 1997. A Common Wealth: museums and learning in the United Kingdom, London: Department of National Heritage.

Black, Graham. 2005. The Engaging Museum, London: Routledge.

Black, Graham. 2008. Creating a Museum Learning Environment. In Heritage Learning Matters. Museums and Universal Heritage, ed. Hadwig Kraeutler, 63-76. Vienna:

Schlebrügge.

Cameron, Fiona. 2003. Transcending fear - engaging emotions and opinion - a case for museums in the $21^{\text {st }}$ century. Open Museum Journal 6: 1-46.

Cameron, Fiona. 2005. Contentiousness and shifting knowledge paradigms: the roles of history and science museums in contemporary society. Museum Management and Curatorship 20(2): 213-33.

Centre for Civil Society, London School of Economics. 2004 What is Civil Society? Available at www.Ise.ac.uk/collections/CCS/what is civil society.htm (Accessed March 2009)

Ciolfi, Luigina, Liam J. Bannon and Mikael Fernström. 2008. Including Visitor Contributions in Cultural Heritage Installations: Designing for Participation. Museum Management and Curatorship 23 (4): 53-65.

Conwill, Kinshasa Holman and Alexandra Marmion Roosa. 2003. Cultivating Community Connections. Museum News May/June 2003. Available at http://www.aamus.org/pubs/mn/MN MJ03 CommConnections.cfm (Accessed August 2009).

Connerton, Paul. 1989. How Societies Remember. Cambridge: Cambridge University Press.

Cooks, Roberta. 1999. Is there a way to make controversial exhibits that work? Journal of Museum Education 23(3): 18-20.

Crane, Susan A. 2000. Museums and Memory. Stanford CA: Stanford University Press.

Crooke, Elizabeth. 2008. An Exploration of the Connections among Museums, Community and Heritage. In The Ashgate Research Companion to Heritage and Identity, ed. Brian Graham and Peter Howard, 415-424. Aldershot: Ashgate. 
Embedding user and community participation and civil engagement in museum display and programming

Davis, Peter. 2008. New Museologies and the Ecomuseum. In The Ashgate Research Companion to Heritage and Identity, ed. Brian Graham and Peter Howard, 397-414. Aldershot: Ashgate.

Department for Communities and Local Government. 2008. Communities in Control: real people, real power. London: DCLG. Available at www.communities.gov.uk/documents/communities/pdf/886045.pdf (Accessed January 2009).

Deuel, Jon, Jenny Sayre Ramberg, John Fraser and Tom Hanchett. 2007. Inspiring Visitor Action in Museums: Examining the Social Diffusion of Ideas, COURAGE and Time's Running Out - Act Now, The Exhibitionist, Fall 2007: 20-31.

Economou, Maria. 2004. Evaluation Strategies in the Cultural Sector: The case of Kelvingrove Museum and Art Gallery. Museum and Society 2(1): 30-46.

Falk, John. 2009. Identity and the Museum Visitor Experience. Walnut Creek CA: Left Coast Press.

Falk, John, Lynn D. Dierking and Susan Foutz, eds. 2007. In Principle In Practice, Lanham MD: AltaMira Press

Falk, John and Lynn D. Dierking. 2002. Lessons Without Limit: How Free-choice Learning is Transforming Education, Lanham MD: AltaMira Press.

Falk, John and Lynn D. Dierking. 2000. Learning from Museums, Lanham MD: AltaMira Press.

Fleming, David. 2005. Managing Change in Museums. Museums and Change International Conference, Prague, November 2005.

Gates, Christopher T. 2001. Forum: Democracy \& the Civic Museum. Museum News May/June 2001. Available at www.aam-us.org/pubs/mn/MN MJ01 DemocracyMuseum.cfm (Accessed July 2009).

Goodin, Robert E. 2003. Reflective Democracy, Oxford: Oxford University Press.

Griffin, Des and Maurice Abraham. 2001. The effective management of museums: Cohesive leadership and visitor-focused public programming. International Journal of Museum Management and Curatorship 18(4): 335-368.

Gurian, Elaine Heumann (2006) 'Threshold Fear' in Gurian, E.H. Civilizing the Museum, London: Routledge, 115-126.

Hood, Marilyn G. 1993. After 70 Years of Audience Research, What Have We Learned? Who Comes to Museums, Who Does Not, and Why? in Visitor Studies, Theory, Research and Practice, 5, ed. Thompson, D. et al, 77-87. Jacksonville: Visitor Studies Association.

Janes, Robert R. 2009. Museums in a Troubled World, London: Routledge.

Jolly, Eric J. 2009. Testimony of Dr. Eric J. Jolly, president, Science Museum of Minnesota on "Examining the role of museums and libraries in strengthening communities" before the House Committee of Education and Labor at the Subcommittee on Healthy Families and Communities, September 11, 2008. In Role of Museums and Libraries in Strengthening Communities, ed. Tomas V. Alizar, 87-97. New York: Nova Science Publishers, Inc. 
Embedding user and community participation and civil engagement in museum display and programming

Jones, lan, Robert R. MacDonald and Darryl Mclntyre. 2008. City Museums and City Development. Lanham MD: AltaMira Press.

Jones, Ian. 2008. Cities and Museums about Them. In City Museums and City Development, eds. Jones, lan, Robert R. MacDonald and Darryl Mclntyre Jones, Ian, Robert R. MacDonald and Darryl Mclntyre, 1-15. Lanham MD: AltaMira Press.

Kistemaker, Renee. 2006. City Museums as Centres of Civic Dialogue. Proceedings of the Fourth Conference of the International Association of City Museums, Amsterdam, 3-5 November 2005. Amsterdam: Amsterdam Historical Museum. Available at http://www.knaw.nl/publicaties/pdf/20051108.pdf (Accessed March 2008).

Low, Theodore L. 1942 The Museum as a Social Instrument, New York: Metropolitan Museum of Art, for American Association of Museums.

Lubar, Steven. 1997. Exhibiting Memories. In Exhibiting Dilemmas: issues of representation at the Smithsonian, eds. Henderson, A. \& Kaeppler, A.L., 15-27. Washington: Smithsonian Institution.

McLean, Fiona. 2008. Museums and the Representation of Identity. In The Ashgate Research Companion to Heritage and Identity, ed. Brian Graham and Peter Howard, 283296. Aldershot: Ashgate.

McLean, Fiona and Steven Cooke. 2003. Constructing the Identity of a Nation: The Tourist Gaze at the Museum of Scotland, Tourism, Culture and Communication 4: 153-162.

McRainey, D. Lynn. 2008. New Directions in Adult Education, Journal of Museum Education 33(1): $33-42$

Mezaros, Cheryl. 2008. Un/Familiar. Journal of Museum Education 33(3): 239-246 Misztal, Barbara A. 2003. Theories of Social Remembering. Maidenhead: Open University Press.

Nakou, Irene. 2005. Oral History, Museums and History Education. Paper presented at conference Can Oral History Make Objects Speak?, ICOM: ICME, Greece, October 2005. Available at www.museumsnett.no/alias/HJEMMESIDE/icme/icme2005/nakou.pdf (Accessed March 2008).

Pedretti, Erminia. 2002. T. Kuhn meets T. Rex: Critical conversations and new directions in science centers and science museums. Studies in Science Education, 37, 1-42.

Phillips, Will (u/d) The Three Agendas. Available at http://qm2.org/mbriefs/32.html (Accessed August 2009).

Reader, John. 2004. Cities London: Heinemann.

Samis, Peter. 2007. New technologies as Part of a Comprehensive Interpretive Plan. In The Digital Museum: a think guide, eds. Herminia Din and Phyllis Hecht, 19-34. Washington: American Association of Museums.

Simon, Nina. 2007a. Beyond Hands-on: Web 2.0 and New Models for Engagement. Hand to Hand 21(4), winter 2007. Available at www.museumtwo.com/publications/beyond hands on.pdf (Accessed January 2009). 
Embedding user and community participation and civil engagement in museum display and programming

Simon, Nina. 2007b. Museum 2.0 blogspot 20/03/2007: Hierarchy of social participation. Available at http://museumtwo.blogspot.com/2007/03/hierarchy-of-social-participation.html (Accessed January 2009).

Simon, Nina. 2008a. Museum 2.0 blogspot 08/10/2008: The future of authority: platform power. Available at http://museumtwo.blogspot.com/2008/10/future-of-authority-platformpower.html (Accessed January 2009).

Simon, Nina. 2008b. Museum 2.0 blogspot 20/11/2008: Free2Choose and the Social Dimension of Polling Interactives. Available at http://museumtwo.blogspot.com/2008/11/free2choose-and-social-dimension-of.html (Accessed January 2009).

Szekeres, Viv. 2007. Representing Diversity and Challenging Racism: the Migration Museum. In Museums and their Communities, ed. Shiela Watson, 234-243. London: Routledge.

Thelen, David. 2001. Learning Community: Lessons in Co-creating the Civic Museum, Museum News May/June 2001. Available at www. aamus.org/pubs/mn/MN MJ01 LearningCommunity.cfm (Accessed August 2009).

Tosh, John with Sean Lang. $4^{\text {th }}$ ed. 2006. The Pursuit of History Harlow: Pearson Longman. Underhill, Paco. 1999. Why we Buy: the science of shopping London: Orion Publishing.

Uzzell, David. 1989. The Hot Interpretation of War and Conflict, in Heritage Interpretation Vol. 1: the natural and built environment, ed. David Uzzell, 33-47. London: Belhaven Press.

Wilkening, Susie and James Chung. 2009. Life Stages of the Museum Visitor: building engagement over a lifetime Washington: American Association of Museums Press.

Wilton, Janis. 2006. Museums and Memories: remembering the past in local and community museums. Public History Review 12, 58-79.

Wong, Judy L. 2002. Who We Are. Interpretation Journal, 7(2), Summer 2002, 4-7

Woroncow, Barbara. 2001. Heritage for All: ethnic minority attitudes to museums and heritage sites. Paper presented to the ICOM Triennial Conference, Barcelona, July 2001. Available at http://icom.museum/icme (Accessed January 2004).

Worts, Douglas. 2006. Measuring museum meaning: A critical assessment framework. Journal of Museum Education, 31, 41-48. 